\title{
TECHNICAL FEASIBILITY STUDY MODEL OF AGED APARTMENT RENOVATION APPLYING ANALYTIC HIERARCHY PROCESS
}

\author{
Junho CHOI ${ }^{1}$, Jaepil $\mathrm{CHOI}^{2 *}$ \\ ${ }^{1}$ Institute of Construction and Environment Engineering, Seoul National University, Seoul, South Korea \\ ${ }^{2}$ Department of Architecture and Architectural Engineering, Seoul National University, Seoul, South Korea
}

Received 29 July 2021; accepted 20 October 2021; first published online 30 December 2021

\begin{abstract}
Residential buildings are being renovated around the world, especially apartments, their solutions are becoming increasingly important. The number of apartments in Korea that are more than 20 years old has reached 4.3 million, and the problem of aged apartments now needs to be addressed. Consequently, the government is promoting the improvement of the residential environment through renovation. In a renovation project, a feasibility study is conducted at the outset, but many apartments fail to complete the renovation process during the project. One reason is that feasibility studies focus on economics without sufficiently considering the technical aspects of the redesign. This study developed a feasibility study model that can pre-evaluate apartment renovation in terms of technology. We selected 27 criteria that affect technical feasibility, and the analytic hierarchy process (AHP) was performed with experts to derive the relative importance of the criteria. Based on the weight of the criteria, we developed an apartment renovation technology feasibility study model. As a result of the study, unit and complex conditions were found to have a significant influence on renovation. Moreover, it was found that the technical feasibility study model can quantitatively evaluate the technical aspects of an apartment to be renovated.
\end{abstract}

Keywords: aged apartment, renovation, rehabilitation, retrofitting, remodeling, technical feasibility study, analytic hierarchy process.

\section{Introduction}

Building renovation is widely embraced because it creates a pleasant and sustainable living environment and reuses resources (Baek \& Park, 2012). Residential buildings are being renovated around the world, especially apartments, and their solutions are becoming increasingly important (Kaklauskas et al., 2013; Yoon \& Yu, 2019). In Korea, a representative housing type is the apartment, which accounts for more than $60 \%$ of the total housing (Moon, 2020). Additionally, the number of apartments over 20 years old exceeds 4.7 million (Kim et al., 2020). In particular, many apartments built in the Seoul metropolitan area to solve housing shortages in the 1990s are now aging and becoming a significant problem (Choi et al., 2018; Yoon \& Yu, 2019).

Reconstruction and renovation are established methods of solving the problem of aged apartments. Reconstruction is a method of dismantling an existing construction and building a new one, while renovation is a method of improving and repairing the structure of an existing building (Choi et al., 2018). Apartment renova- tion in Korea includes not only the repair and expansion of the household floor, but also the vertical extension of the upper section of the building and the extension of the underground parking (Yoon \& Yu, 2019; Seo et al., 2021). Figure 1 shows the concept of extension-type renovation. The blue color represents existing buildings, whereas yellow indicates the extension parts. Through renovation, these are extended to the front and rear, and 1-3 floors are extended vertically. The renovation also includes the construction of an underground parking lot between the buildings.

The Korean government has encouraged apartment renovation by enacting a bill that provides incentives for it. Expansion of the floor plan is permitted through renovation, and vertical extensions are allowed for new housing units (Choi et al., 2017). Moreover, the city of Seoul is supporting renovation by proposing a master plan for the renovation of aged apartments and a selection of pilot projects. Consequently, many apartments in and around Seoul are pursuing renovation projects.

*Corresponding author. E-mail: jpchoi@snu.ac.kr 


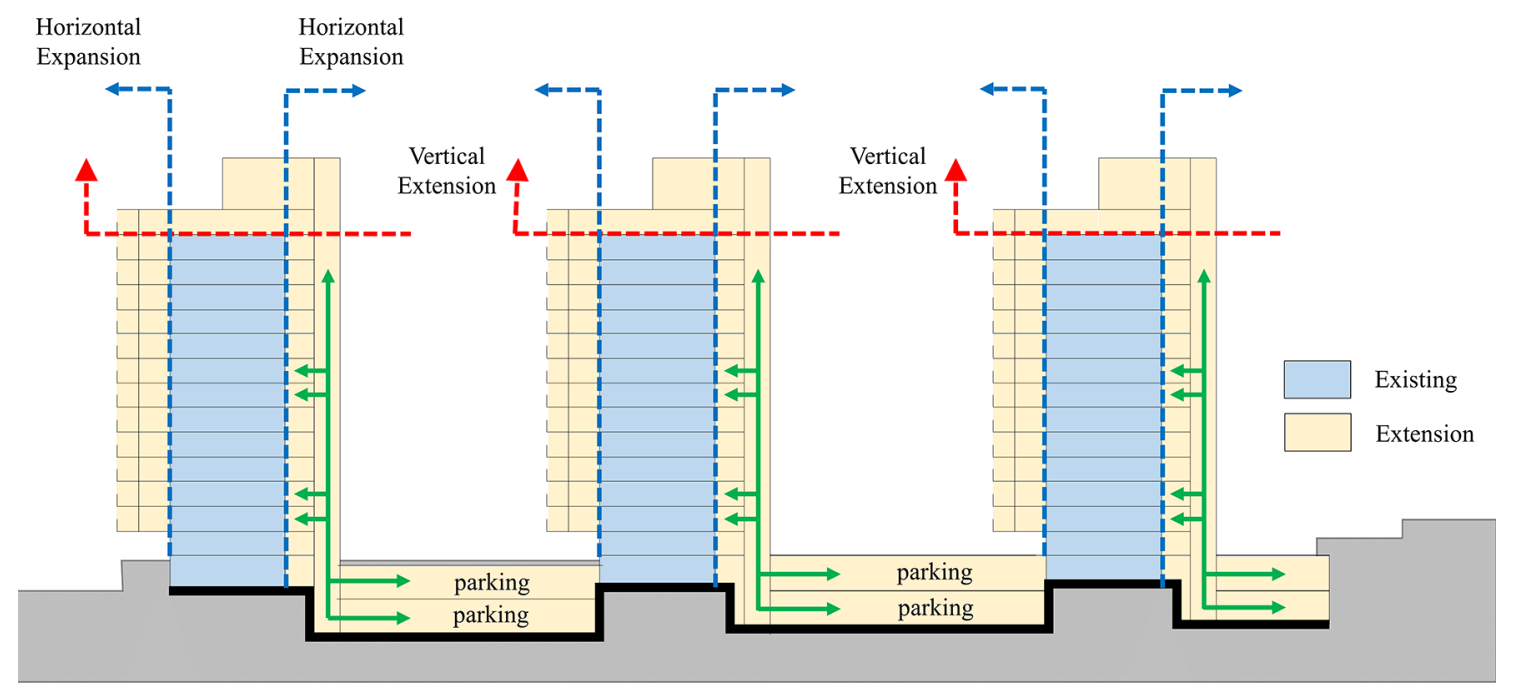

Figure 1. Concept of extension-type renovation

To conduct such a project, a feasibility study is required. However, residential building renovation feasibility studies have mainly focused on economic feasibilities such as the costs and project profitability (Hopkins et al., 2006; Boeri et al., 2011). Similarly, feasibility studies of apartment renovations in Korea tend to be evaluated based primarily on their economic feasibility and business efficiency - such as return on investment and project timescale projections (Yeon et al., 2014; Koh et al., 2019; Yoon \& Yu, 2019). The problem is that many apartments earmarked for renovation based on a pre-evaluation process that considered economic feasibility alone, did not actually complete the renovation process.

Renovation is the redesign of a building based on its existing conditions. From a technical viewpoint, the physical condition of the complex, building, or unit should be examined to determine whether it is appropriate for renovation (J. Choi \& J. Choi, 2021). For example, the project should be planned based on the complex layout, the characteristics of the building structure, its load-bearing wall configurations, etc. However, existing feasibility studies do not reflect these technical factors. If a method for objectively evaluating the technical aspects of apartment renovation were to be proposed, and included in the preevaluation process, the initial risk of the renovation project could be reduced, and a more accurate pre-evaluation process would be made possible.

Consequently, the purpose of this study is to quantify the technological impact affecting aged apartment renovation projects and to derive a technology feasibility evaluation model that could supplement existing economic feasibility studies. We derived the criteria for evaluating the technical feasibility of aged apartments based on previous studies and performed analytic hierarchy process (AHP) analysis with renovation experts to derive the relative weight of the criteria. Furthermore, we developed a technical feasibility study model reflecting the criteria weights. The model was first verified through the evalua- tion of apartments that had already been renovated, and later through the evaluation of apartments currently in the process of renovation.

\section{Literature review}

\subsection{Feasibility study of apartment renovation}

The early feasibility studies of apartment renovations have been conducted in terms of economic feasibility, project duration, and energy efficiency.

Hopkins et al. (2006) evaluated the feasibility based on the economic costs and benefits of retrofitting an aged apartment building in Istanbul. Boeri et al. (2011) analyzed the economic impact of retrofitting social housing in Italy. To analyze the economic aspects, a study on the initial investment cost of the project was conducted by applying discounted cash flow analysis techniques. Paiho et al. (2012) evaluated the feasibility of modernization and energy improvement of an apartment building in Moscow through renovation. Yeon et al. (2014) supplemented the net present value technique applied to the feasibility evaluation of apartment renovation in Korea and conducted a feasibility study reflecting the renovation process. Yoon and $\mathrm{Yu}$ (2019) studied project duration predictions for vertical extension renovation of apartments. They classified the renovation project process, and applied the Monte Carlo simulation to predict the project period. Koh et al. (2019) developed an evaluation model that could determine the return on investment based on construction, project, and financial costs at the initial stage of a renovation project. Tan et al. (2018) reviewed feasible retrofit technologies that can be applied from the perspective of green retrofit to aged residential buildings in Hong Kong. Ahmed and Asif (2020) studied techno-economic assessment for energy retrofitting in residential buildings in hot, humid climates. Through a BIM-based approach, the construction characteristics of villa and apartment buildings were investigated, and three levels of energy retrofitting 
were discussed. Other studies pre-evaluated the change in energy efficiency based on changes of the facility system (Biekša et al., 2011; Kragh \& Rose, 2011; Ouyang et al., 2011; Bianchi et al., 2012; Ehyaei et al., 2012).

In summary, renovation - that is, rehabilitation, retrofitting, and remodeling - is the redesign of an existing building, and a feasibility study on the physical characteristics of the building and the technology to be applied should also be considered. Previous studies (Tan et al., 2018; Ahmed \& Asif, 2020) have dealt with these aspects, but they have not been sufficiently considered.

\subsection{Physical and technical conditions for apartment renovation}

Research on the physical conditions and technical aspects started in early 2000s in terms of renovating aged apartments in Korea.

Ministry of Construction and Transportation (2001) proposed a checklist for the requirements of an existing building earmarked for renovation. Although the checklist was derived based on flexibility, the derived criteria were limited and did not reflect the characteristics of extended renovation. Korea National Housing Corporation (2001) studied design standards for renovations of walltype apartments. This study categorized apartments into 12 wall-types and suggested a renovation design for each of them. However, the research was focused on passive renovation and the evaluation indicators were not comprehensive.

Cha et al. (2008) studied the renovation feasibility evaluation system of an existing apartment from the perspective of building demolition and dismantling. They divided renovation feasibility evaluation criteria into macro-level and micro-level criteria, and proposed an evaluation method. Evaluation indicators included the building-to-land ratio, floor area ratio, floor height, and load-bearing wall weight. However, evaluation indicators were not examined based on renovation construction cases, and more recent apartment renovation methods were not considered. Ministry of Land and Maritime Affairs (2011) studied the house performance rating evaluation manual. Since this manual was intended to evaluate the housing performance of new apartments, it was difficult to evaluate the technical aspects of existing buildings in terms of renovation.
Kim and Cha (2018) conducted a study on apartment renovation cost estimation through influence analysis using design elements. Based on apartment renovation completion case data, the effects of design factors on construction costs were established. Although this study determined the relationship between the technology applied to apartment renovation and the construction cost, there was a limit to its applicability to the pre-evaluation of apartment renovation because the study was conducted in terms of applied design technology rather than the conditions of existing apartments. A study by J. Choi and J. Choi (2021) derived the technology feasibility evaluation criteria for apartment renovation through the Delphi method. The Delphi method was performed by four experts from the fields of design, structure, construction, and construction management, with 5 to 15 years of experience in apartment renovation projects and government research and development projects. It was meaningful that they derived evaluation criteria related to the condition of existing apartments, and factors newly considered in apartment renovations. However, since the relative importance of each criterion had not been established, there was a limit on quantifying and evaluating the apartments to be renovated.

Although there have been studies from various perspectives on the technical aspects of apartment renovation in Korea, studies that can quantitatively evaluate project feasibility based on the conditions of existing buildings have not progressed. In this study, we selected the criteria for evaluating the technical feasibility of apartment renovation in the initial stage, and examined a quantitative evaluation model based on the relative importance of the criteria.

\section{Methods}

The study was conducted in three stages (see Figure 2). In the first stage, based on previous studies, the feasibility evaluation criteria for the renovation of aged apartments were selected. In the second stage, weights were derived using the AHP methodology for selected criteria, and based on this, a feasibility evaluation model for aged apartment technology was developed. In the third stage, we verified the model for the apartment where the renovation project was conducted.
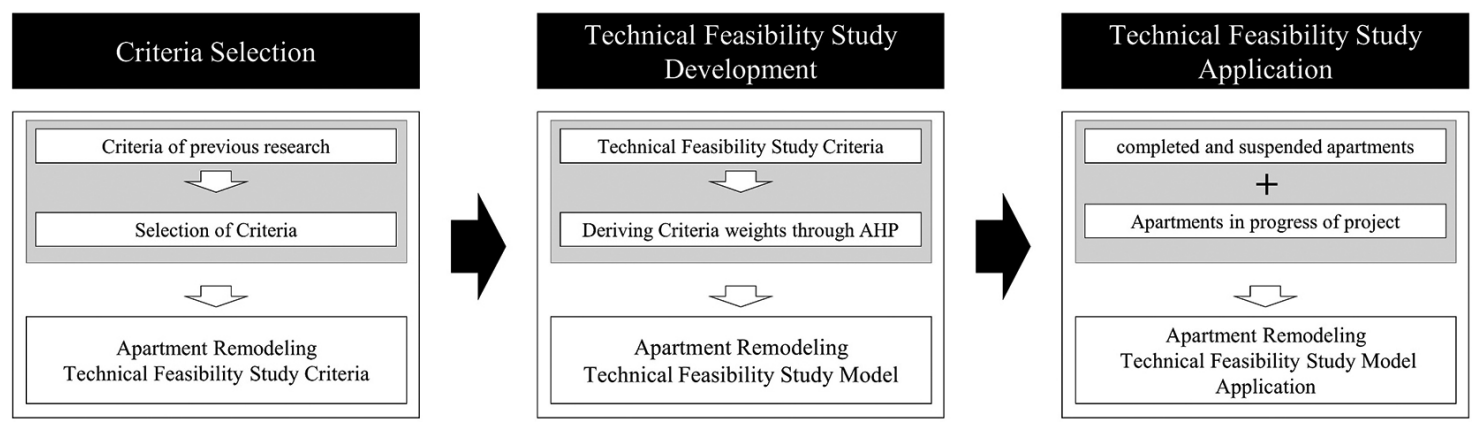

Figure 2. Research method 


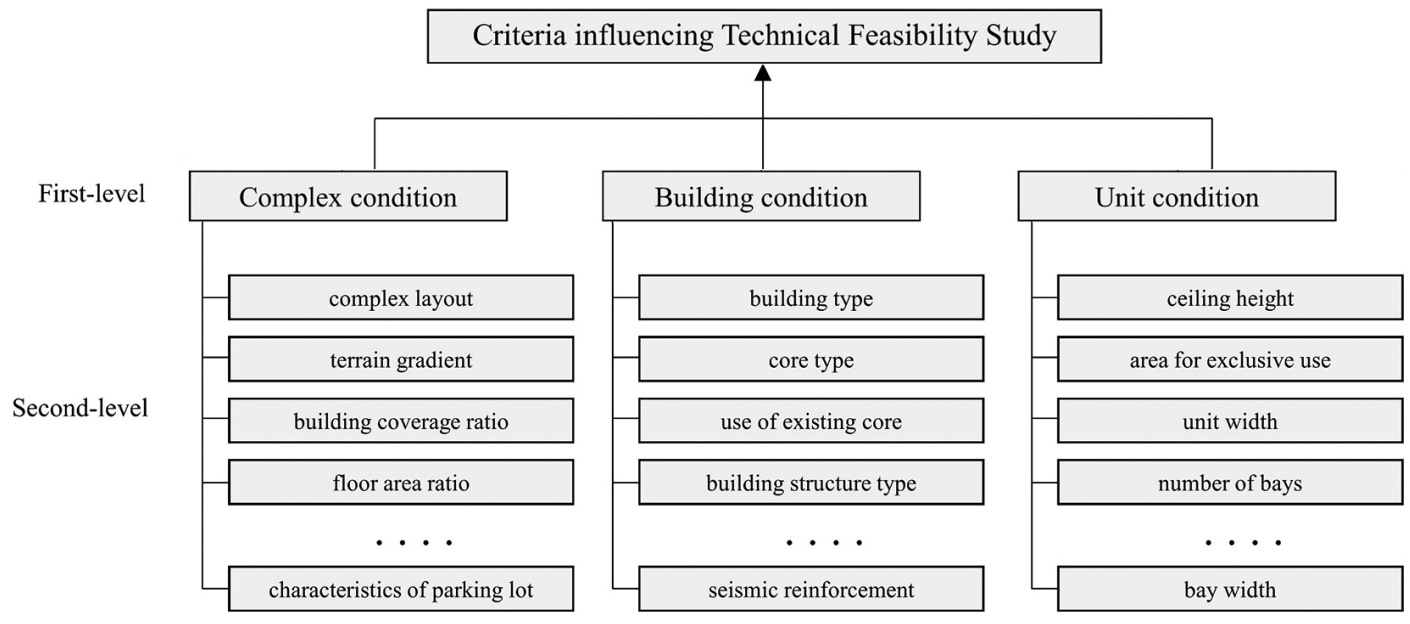

Figure 3. Hierarchical structure of technology feasibility evaluation criteria

\subsection{Selection of technical feasibility study criteria}

The selection of criteria affecting the feasibility of aged apartment renovation techniques was based on the work of J. Choi and J. Choi (2021). It derived the evaluation criteria for the condition of a complex, building, or unit using the Delphi analysis method. In this study, 27 independent criteria were selected based on the characteristics of the model among the criteria for evaluating technical feasibility. 10 complex condition criteria, 11 building condition criteria, and 6-unit condition criteria were selected. Figure 3 shows the hierarchy and composition of the 27 criteria. To evaluate the technical feasibility study of an aged apartment, we planned three first-level criteria and 27 second-level criteria.

Complex conditions (A) have the following 10 secondlevel criteria: complex layout (A1), terrain gradient (A2), building coverage ratio (A3), floor area ratio (A4), empty land condition for new building (A5), building extension condition (A6), distance between buildings (A7), ancient lights (A8), ground condition (A9), and characteristics of the parking lot (A10).

Building conditions (B) have the following 11 secondlevel criteria: building floors (B1), building type (B2), stairs core type (B3), stairs core form (B4), use of existing stairs core (B5), building-parking lot elevator connection (b6), building structure type (B7), foundation structure type (B8), structural safety grade (B9), seismic reinforcement (B10), building-parking structure separation (B11).

Unit conditions (C) have the following 6 second-level criteria: ceiling height $(\mathrm{C} 1)$, area for exclusive use (C2), unit width (C3), number of bays (C4), bay width (C5), load-bearing wall length ratio (C6).

Table 1 shows the descriptions of the 27 criteria for evaluating the technical feasibility study of apartment renovation. Among the 27 criteria, complex layout (A1), empty land condition for new building (A5), ground condition (A9), characteristics of parking lot (A10), building floors (B1), stair core type (B3), building-parking lot el- evator (B6), building-parking structure (B11), and area for exclusive use (C2) take discrete values, and the other 18 criteria take continuous values.

Figure 4 shows how each criterion appears in the Complex, Building, and Unit hierarchy of the existing apartment building.

\subsection{Deriving criteria weights applying AHP analysis}

AHP analysis has been applied in various fields as a method for deriving the relative importance between criteria through expert questionnaires (Tupenaite et al., 2010; Kaklauskas et al., 2013). The reliability of the analysis results can be tested through a consistency test (Lai et al., 2008; Chen et al., 2014). Since the analysis is performed based on an expert questionnaire, it is important to select an expert who can objectively evaluate the importance of the criteria. In this study, an expert group was formed comprising of experts in the field with experience in apartment renovation projects.

The methodology was applied as described in Figure 5.

1. Structuring: For the structure of the criteria, a spatial hierarchy (complex, building, unit) was applied, then divided into first-level and second-level criteria (Figure 4).

2. Weighting: For weightings between the criteria, a paired comparison method was applied. The relative importance of first-level (complex, build, unit) and second-level criteria was examined.

3. Consistency test: The AHP method finds errors in the survey results through consistency tests. If the consistency index is less than 0.1 , the analysis results are deemed to be reliable.

4. Prioritization: The weightings between criteria were derived so that their sum is 1 . The weights of the complex, building, and unit were derived, and the final weight was determined by examining whether the consistency index value was less than 0.1 . 
Table 1. Criteria for renovation technology feasibility study

\begin{tabular}{|c|c|c|}
\hline Criteria & Description & Range of scores \\
\hline \multicolumn{3}{|c|}{ Complex conditions } \\
\hline A1. Complex layout & $\begin{array}{l}\text { Is the complex layout formal? } \\
\text { (The apartment complex layout influences the parking lot plan and the new } \\
\text { building plan) }\end{array}$ & 0 (informal), 1 (formal) \\
\hline $\begin{array}{l}\text { A2. Terrain } \\
\text { gradient }\end{array}$ & $\begin{array}{l}\text { Is the terrain of the complex flat? } \\
\text { (The terrain gradient of an apartment complex affects the renovation cost) }\end{array}$ & 0 (sloping) $\sim 1$ (flat) \\
\hline $\begin{array}{l}\text { A3. Building } \\
\text { coverage ratio }\end{array}$ & $\begin{array}{l}\text { Is the building-to-cover ratio low? } \\
\text { (A low building-to-coverage ratio is advantageous for the extension of buildings } \\
\text { and parking lots) }\end{array}$ & 0 (high) $\sim 1$ (low) \\
\hline A4. Floor area ratio & $\begin{array}{l}\text { Is the floor area ratio low? } \\
\text { (A low floor area ratio is advantageous for building extensions and it reduces } \\
\text { construction costs) }\end{array}$ & 0 (high) $\sim 1$ (low) \\
\hline $\begin{array}{l}\text { A5. Empty land } \\
\text { condition for new } \\
\text { building }\end{array}$ & $\begin{array}{l}\text { Is there empty land for new buildings? } \\
\text { (Instead of vertical extension, new buildings on empty land reduce the } \\
\text { construction cost) }\end{array}$ & 0 (No), 1 (Yes) \\
\hline $\begin{array}{l}\text { A6. Building } \\
\text { extension condition }\end{array}$ & $\begin{array}{l}\text { Is there space to extend the front and rear? } \\
\text { (Front and rear spaces are required for the expansion of the building) }\end{array}$ & $\begin{array}{l}0 \text { (insufficient) } \sim 1 \\
\text { (sufficient) }\end{array}$ \\
\hline $\begin{array}{l}\text { A7. Distance } \\
\text { between buildings }\end{array}$ & $\begin{array}{l}\text { Is there sufficient space between buildings? } \\
\text { (Distance between buildings affects parking lot and building expansion) }\end{array}$ & 0 (close) $\sim 1$ (far) \\
\hline A8. Ancient lights & $\begin{array}{l}\text { Are the building extensions limited by the ancient light? } \\
\text { (The ancient light of the adjacent building restricts the vertical extension of the } \\
\text { building) }\end{array}$ & 0 (a lot) $\sim 1$ (a little) \\
\hline $\begin{array}{l}\text { A9. Ground } \\
\text { condition }\end{array}$ & $\begin{array}{l}\text { Is there rock in the ground? } \\
\text { (Rocks in the ground make it difficult to expand the underground parking lot) }\end{array}$ & 0 (Yes), 1 (No) \\
\hline $\begin{array}{l}\text { A10. Characteristics } \\
\text { of parking lot }\end{array}$ & $\begin{array}{l}\text { Is there an underground parking lot? } \\
\text { (To build a new underground parking lot, the existing underground parking lot } \\
\text { needs to be demolished) }\end{array}$ & 0 (Yes), $1(\mathrm{No})$ \\
\hline \multicolumn{3}{|c|}{ Building conditions } \\
\hline B1. Building floors & $\begin{array}{l}\text { Does the building have more than } 15 \text { floors? } \\
\text { (Buildings with more than } 15 \text { floors have a stronger foundation structure, so they } \\
\text { are easy to extend vertically) }\end{array}$ & 0 (No), 1 (Yes) \\
\hline B2. Building type & $\begin{array}{l}\text { Is the building flat type? } \\
\text { (A flat-type building is easier to renovate than other types) }\end{array}$ & 0 (mixed) $\sim 1$ (flat) \\
\hline B3. Stairs core type & $\begin{array}{l}\text { Is it a stair-type core system? } \\
\text { (Corridor-type buildings require a new staircase) }\end{array}$ & 0 (No), 1(Yes) \\
\hline B4. Stairs core form & $\begin{array}{l}\text { Is it easy to renovate the form of stair core? } \\
\text { (Does the stair core have a suitable form for renovation?) }\end{array}$ & 0 (Poor) 1 (Good) \\
\hline $\begin{array}{l}\text { B5. Use of existing } \\
\text { stairs core }\end{array}$ & $\begin{array}{l}\text { Is the existing stairs core reusable? } \\
\text { (The use of the existing stair core reduces structural reinforcement costs and } \\
\text { increases structural safety) }\end{array}$ & 0 (little) $\sim 1$ (mostly) \\
\hline $\begin{array}{l}\text { B6. Building- } \\
\text { parking lot elev. }\end{array}$ & $\begin{array}{l}\text { Can the building and underground parking lot be connected easily via an elevator? } \\
\text { (The difficulty in connecting the elevator to the building and the parking lot affects } \\
\text { the construction cost) }\end{array}$ & 0 (easy) 1 (difficulty) \\
\hline $\begin{array}{l}\text { B7. Building } \\
\text { structure type }\end{array}$ & $\begin{array}{l}\text { Does the building have a wall structure? } \\
\text { (The rahmen structure type is easier to renovate than the wall-type structure) }\end{array}$ & 0 (Wall) $\sim 1$ (Rahmen) \\
\hline $\begin{array}{l}\text { B8. Foundation } \\
\text { structure type }\end{array}$ & $\begin{array}{l}\text { Is there a mat foundation? } \\
\text { (The mat foundation type is easier to reinforce than the pile foundation type) }\end{array}$ & 0 (pile) $\sim 1$ (mat) \\
\hline $\begin{array}{l}\text { B9. Structural safety } \\
\text { grade }\end{array}$ & $\begin{array}{l}\text { What is the safety rating of the building? } \\
\text { (A high safety grade reduces the cost of structural reinforcement) }\end{array}$ & 0 (low) $\sim 1$ (high) \\
\hline $\begin{array}{l}\text { B10. Seismic } \\
\text { reinforcement }\end{array}$ & $\begin{array}{l}\text { Is there seismic reinforcement? } \\
\text { (The degree of seismic reinforcement of an existing building affects the structural } \\
\text { reinforcement) }\end{array}$ & 0 (a little) $\sim 1$ (much) \\
\hline $\begin{array}{l}\text { B11. Building- } \\
\text { parking structure }\end{array}$ & $\begin{array}{l}\text { Are the building and parking structures separated? } \\
\text { (The separation of the building and parking lot affects the construction cost) }\end{array}$ & 0 (No), 1 (Yes) \\
\hline
\end{tabular}


End of Table 1

\begin{tabular}{|c|c|c|}
\hline Criteria & Description & Range of scores \\
\hline \multicolumn{3}{|c|}{ Unit conditions } \\
\hline C1. Ceiling height & $\begin{array}{l}\text { Is the ceiling height high enough? } \\
\text { (Ceiling heights influence plumbing for air conditioning, sprinklers, lighting, etc.) }\end{array}$ & 0 (Low) $\sim 1$ (High) \\
\hline $\begin{array}{l}\text { C2. Area for } \\
\text { exclusive use }\end{array}$ & $\begin{array}{l}\text { Is the unit area less than } 85 \text { square meters? } \\
\text { (Additional extensions are permitted for buildings of } 85 \text { square meters or less. } \\
{ }^{*} \text { Domestic rules) }\end{array}$ & 0 (No), 1 (Yes) \\
\hline C3. Unit width & $\begin{array}{l}\text { Is the unit width wide? } \\
\text { (The width of the unit affects the lighting and natural ventilation) }\end{array}$ & 0 (Narrow) $\sim 1$ (Wide) \\
\hline C4. Number of bays & $\begin{array}{l}\text { How many bays? } \\
\text { (The number of bays affects the demolition and renovation plan) }\end{array}$ & 0 (few) $\sim 1$ (many) \\
\hline C5. Bay width & $\begin{array}{l}\text { Is the bay width wide? } \\
\text { (The width of the bay affects lighting, natural ventilation, and evacuation areas) }\end{array}$ & 0 (Narrow) $\sim 1$ (Wide) \\
\hline $\begin{array}{l}\text { C6. Load-bearing } \\
\text { wall length ratio }\end{array}$ & $\begin{array}{l}\text { Is the bearing wall ratio small? } \\
\text { (A low load-bearing wall ratio is advantageous for floor plan designing through } \\
\text { renovation) }\end{array}$ & 0 (High) $\sim 1$ (Low) \\
\hline
\end{tabular}

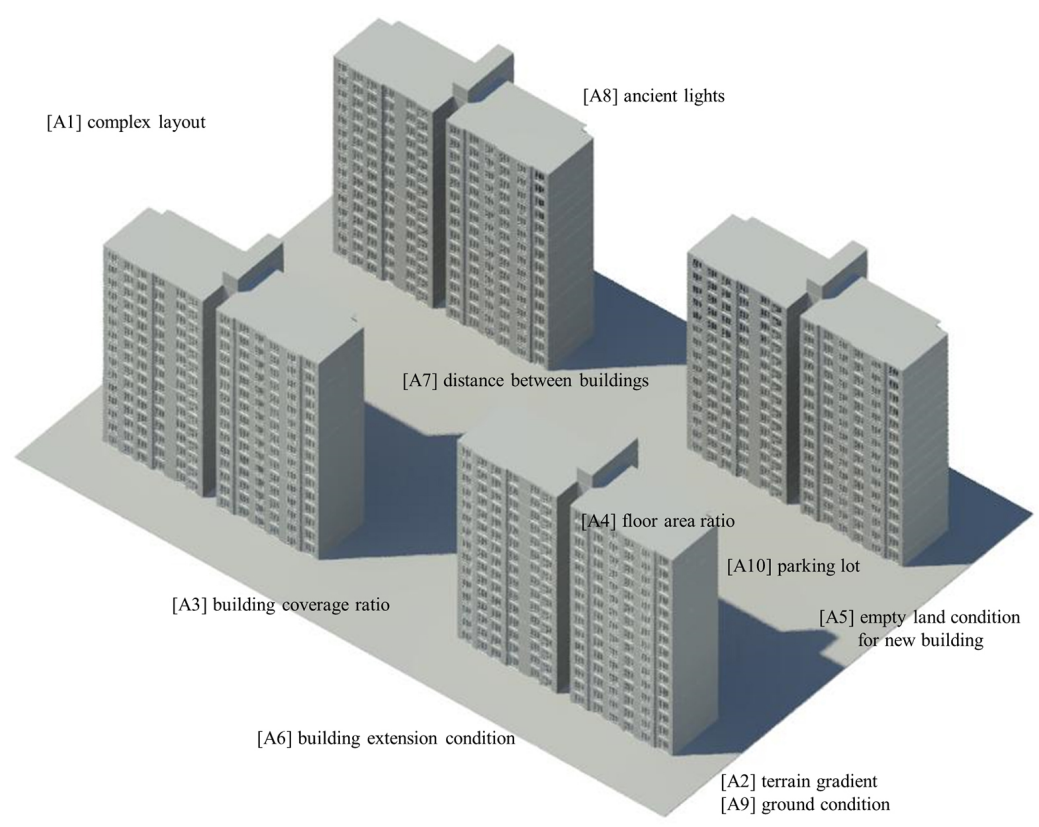

Complex condition

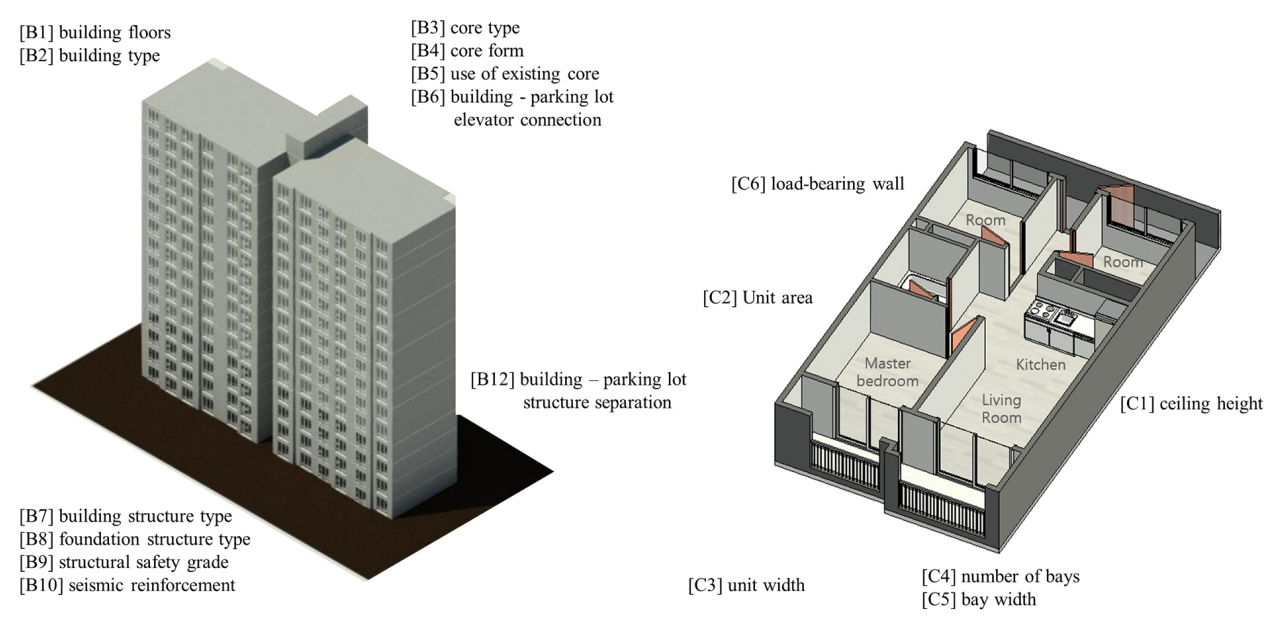

Building condition

Unit condition

Figure 4. Spatial hierarchy of an apartment 


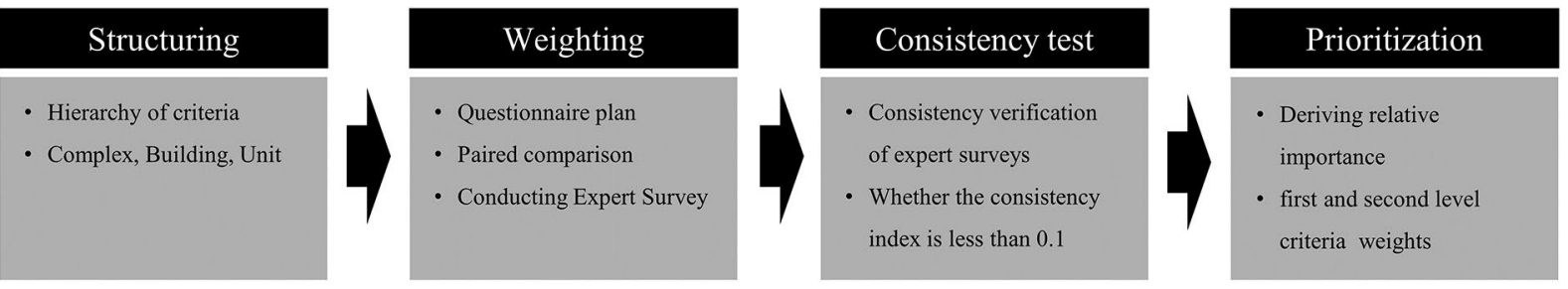

Figure 5. The process for the AHP method

\section{Technology feasibility study model for apartment renovation}

\subsection{Deriving criteria weights by applying AHP}

The AHP questionnaire was conducted with ten experts three design firm executives, one structural expert, two construction experts, three construction management experts, and one construction engineer (Table 2).

AHP analysis was performed based on the questionnaire answered by the ten experts, and as the value of the consistency index was 0.0675 (i.e., less than 0.1 ) the derived weight value was considered to be reliable.

The relative importance of apartment renovation technology feasibility study criteria is as follows (Tables 3 and 4): The first-level criteria importance was shown in the order of unit, complex, and building conditions. The importance of the unit condition was 0.456 , which was found to be the most important compared with the complex and building conditions in terms of technical feasibility. The importance of the complex condition was ranked second, and it was found to have a similar level of importance as the unit condition. The building condition was found to be somewhat less important than the complex and unit conditions.

The importance of the second-level criteria was also derived (Table 4). The complex condition was determined in the order of ancient lights (A8), floor area ratio (A4), and distance between buildings (A7). Ancient lights (A8) is a criterion that has an enormous influence on vertical extension and horizontal expansion. However, floor area ratio (A4) is an important criterion in determining the scale and difficulty of the overall construction. The dis- tance between buildings (A7) is a criterion that has an enormous influence on the horizontal expansion of buildings, the expansion of underground parking lots, and residential comfort.

The importance of the building condition was determined in the order of building-parking lot elevator connection (B6), structural safety grade (B9), and foundation structure type (B8). For the building-parking lot elevator connection (B6), Choi et al. (2011) found it to be the factor that had a great influence on resident satisfaction. The structural safety grade (B9) and foundation structure type (B8) are important criteria for vertical extension renovation. The importance of the unit condition was determined in the order of bay width (C5), the number of bays (C4), and unit width (C3). The bay width (C5) was determined to be the most important criterion in the unit condition. These criteria not only directly affect lighting and natural ventilation, but also evacuation space planning. The number of bays (C4) is a criterion that has an enormous influence on the renovation floor plan. The larger the number of bays, the easier the plan design.

Table 3. Weights of the first-level criteria

\begin{tabular}{|l|c|c|c|}
\hline \multicolumn{1}{|c|}{$\begin{array}{c}\text { First-level } \\
\text { criteria }\end{array}$} & $\begin{array}{c}\text { Weight of first-level } \\
\text { criteria }\end{array}$ & Rank & $\begin{array}{c}\text { Consistency } \\
\text { Index }\end{array}$ \\
\hline $\begin{array}{l}\text { Complex } \\
\text { condition }\end{array}$ & 0.385 & 2 & \multirow{2}{*}{$0.0675<0.1$} \\
\cline { 1 - 3 } $\begin{array}{l}\text { Building } \\
\text { condition }\end{array}$ & 0.158 & 3 & \multirow{2}{*}{1} \\
\cline { 1 - 2 } Unit condition & 0.456 & 1 & \\
\hline
\end{tabular}

Table 2. Characteristics of the expert panel

\begin{tabular}{|l|c|l|l|}
\hline \multicolumn{1}{|c|}{ Division } & Expert & \multicolumn{1}{c|}{ Affiliation } & \multicolumn{1}{c|}{ Work experience } \\
\hline \multirow{3}{*}{ Architectural design } & A & Design firm & 10 years for apartment renovation design \\
\cline { 2 - 4 } & B & Design firm & 15 years for apartment renovation design \\
\cline { 2 - 4 } & C & Design firm & 15 years for apartment renovation design \\
\hline \multirow{2}{*}{ Structure } & D & Structural engineering firm & 20 years for apartment renovation structural design \\
\hline \multirow{3}{*}{ Construction } & E & Construction firm & 15 years for apartment renovation construction \\
\cline { 2 - 4 } & F & Construction firm & 20 years for apartment renovation construction \\
\hline & G & University & 5 years for apartment renovation R\&D project \\
\cline { 2 - 4 } & H & Research Institute & 10 years for apartment renovation planning \\
\cline { 2 - 4 } Construction engineering & I & Research Institute & 5 years for apartment renovation R\&D project \\
\hline
\end{tabular}


Table 4. Second-level criteria weight and rank

\begin{tabular}{|c|c|c|c|c|}
\hline ID & Second-level criteria & Wt of first-level criteria & Wt of second-level criteria & Rank \\
\hline A1 & Complex layout & \multirow{10}{*}{0.385} & 0.02 & 8 \\
\hline A2 & Terrain gradient & & 0.014 & 10 \\
\hline A3 & Building coverage ratio & & 0.019 & 9 \\
\hline A4 & Floor area ratio & & 0.051 & 2 \\
\hline A5 & Empty land condition for new building & & 0.043 & 6 \\
\hline A6 & Building extension condition & & 0.044 & 4 \\
\hline A7 & Distance between buildings & & 0.05 & 3 \\
\hline A8 & Ancient light & & 0.074 & 1 \\
\hline A9 & Ground condition & & 0.026 & 7 \\
\hline A10 & Characteristics of parking lot & & 0.044 & 5 \\
\hline B1 & Building floors & \multirow{11}{*}{0.158} & 0.013 & 7 \\
\hline B2 & Building type & & 0.009 & 9 \\
\hline B3 & Stairs core type & & 0.008 & 10 \\
\hline B4 & Stairs core form & & 0.005 & 11 \\
\hline B5 & Use of existing stairs & & 0.011 & 8 \\
\hline B6 & Building-parking lot elevator connection & & 0.024 & 1 \\
\hline B7 & Building structure type & & 0.017 & 4 \\
\hline B8 & Foundation structure type & & 0.018 & 3 \\
\hline B9 & Structural safety grade & & 0.022 & 2 \\
\hline $\mathrm{B} 10$ & Seismic reinforcement & & 0.015 & 6 \\
\hline B11 & Building-parking structure separation & & 0.016 & 5 \\
\hline $\mathrm{C} 1$ & Ceiling height & \multirow{6}{*}{0.456} & 0.049 & 6 \\
\hline $\mathrm{C} 2$ & Area for exclusive use & & 0.054 & 5 \\
\hline $\mathrm{C} 3$ & Unit width & & 0.07 & 3 \\
\hline $\mathrm{C} 4$ & Number of bays & & 0.103 & 2 \\
\hline $\mathrm{C} 5$ & Bay width & & 0.114 & 1 \\
\hline C6 & Load-bearing wall length ratio & & 0.066 & 4 \\
\hline
\end{tabular}

\subsection{Technology feasibility study model}

The technical feasibility study model applied the simple addictive weighting (SAW) method, which is widely used in multi-criteria decision making (Mulliner et al., 2016; Abastante et al., 2018). Scores were obtained by multiplying the derived weights and standardized criteria values:

$$
A_{i}=\Sigma_{j} w_{j} X_{i j} \text {, }
$$

where $A_{i}$ is the technical feasibility study score of apartment $i ; w_{j}$ is the $j$ criteria weight derived through the AHP, and $X_{i j}$ is the $j$ criteria standardized score of apartment $i$. $w_{i}$ and $x_{i j}$ are represented by values of 0 and 1 .

As the range and scale of each criterion value were varied, it was necessary to standardize the values. In this method, all criteria values have the same scale. For example, the floor area ratio of the apartment had a value ranging from 1.8 to 2.5 and the unit width had a value ranging from $5,700 \mathrm{~mm}$ to $9,800 \mathrm{~mm}$. The value of each criterion was normalized to a value between 0 and 1 . The standardization of criteria values has been applied by various researchers in the field of construction and architecture through the AHP methodology and mathematical models (Abastante et al., 2018; Kafel et al., 2019).

When the attribute value is smaller, the standardization formula for criteria that facilitate renovation feasibility can be expressed as Eqn (2). When the attribute value is higher, the standardization formula for criteria that facilitate renovation feasibility can be expressed as Eqn (3):

$$
\begin{aligned}
& X_{i j}=\frac{x_{j}^{\max }-x_{i j}}{x_{j}^{\max }-x_{j}^{\min }} ; \\
& X_{i j}=\frac{x_{i j}-x_{j}^{\min }}{x_{j}^{\max }-x_{j}^{\min }},
\end{aligned}
$$

where $X_{i j}$ is the standardized value of the $j$ criteria, $x_{i j}$ is the value of the $j$ criteria, $x_{j}^{\max }$ is the maximum value of the $j$ criteria, and $x_{j}^{\min }$ is the minimum value of the $j$ criteria. When the unit width of the apartment $i$ is $6,000 \mathrm{~mm}$, the unit width range for a typical aged apartment in Korea is $5,700 \mathrm{~mm}$ to $9,800 \mathrm{~mm}$. Thus, the standardized value according to Eqn (3) is 0.07 .

\section{Results and discussion: application}

\subsection{Application of model to complete and suspended apartments}

We verified our proposed technical feasibility study model by applying it to apartments where renovation had been completed and suspended. By comparing the apartments, we tried to quantify and evaluate the technical feasibility of each apartment and see whether this model was suitable for evaluating their technical aspects (Table 5). 
Table 5. Result of technical feasibility study on completed and suspended apartments

\begin{tabular}{|c|c|c|c|c|c|c|c|c|}
\hline \multirow{2}{*}{ ID } & \multirow{2}{*}{ Location } & \multirow{2}{*}{ Status } & \multirow{2}{*}{ Apartment } & \multirow{2}{*}{ Structure } & \multicolumn{4}{|c|}{ Technical Feasibility Study Score } \\
\hline & & & & & Complex & Building & Unit & Total \\
\hline 1 & Seoul & \multirow{4}{*}{ Complete } & Bangbae & RC rahmen & 25.81 & 10.41 & 32.56 & 68.78 \\
\hline 2 & Seoul & & Walkerhill & RC wall & 28.64 & 8.75 & 25.16 & 62.56 \\
\hline 3 & Seoul & & Daechi & RC wall & 26.64 & 10.23 & 26.95 & 63.82 \\
\hline 4 & Seoul & & Chungdam & RC wall & 32.49 & 10.29 & 25.8 & 68.59 \\
\hline 5 & Seoul & \multirow{4}{*}{ Suspended } & Dunchon & RC wall & 27.51 & 6.59 & 22.21 & 56.32 \\
\hline 6 & Seoul & & Mapo & RC wall & 16.96 & 7.99 & 20.18 & 45.14 \\
\hline 7 & Seoul & & Sunkyung & RC wall & 16.11 & 7.53 & 23.39 & 47.03 \\
\hline 8 & Seoul & & Dunchon3 & RC wall & 17.21 & 6.7 & 23.77 & 47.68 \\
\hline
\end{tabular}

For the verification, eight apartments located in Seoul were selected. Among the apartment renovation projects between 2007 and 2019, four apartments were completed and four were suspended.

The results were as follows (Table 5, Figure 6). The evaluation score was determined to range from 47.03 to 68.78. Comparing the completed and suspended apartments separately, the evaluation scores of the four completed apartments ranged from 62.56 to 68.78 , and the evaluation scores of the four suspended apartments ranged from 47.03 to 56.32 , the technical feasibility score of the suspended apartments being lower than that of the completed apartments.

Among the completed apartments, the lowest score was 62.56 points (the Walkerhill apartment) and among the suspended apartments, the highest score was 56.32 points (the Dunchon apartment). Considering the evaluation results, it is thought that a renovation project would be able to completed on an apartment with a physical feasibility score of 59 to 60 points or higher.

Although the result of this technical feasibility study model cannot absolutely determine whether the renovation project of a specific apartment is possible, by using the model, it can play a role of supplementing previous renovation projects based on the experience of construction companies. Moreover, the quantitative evaluation score helps to decide whether it is technically feasible for an apartment to be renovated and to gauge the risk thereof.

The spatial hierarchical results of the complex, building, and unit scores indicate that the complex and unit scores had a significant effect on the overall evaluation score (Figure 7).

A detailed examination of the suspended apartments indicate that the Dunchon apartment had a high complex score but a relatively low unit score. Among the unit condition criteria, the unit width and bay width were small, making renovation difficult. In the Dunchon3 apartment, the technical feasibility score of the complex was lower than that of the other apartments. The complex layout was atypical, and it was difficult to expand the front and rear of the building owing to ancient lights. Moreover, the existing underground parking lot had to be demolished for a new parking lot as part of the renovation process.

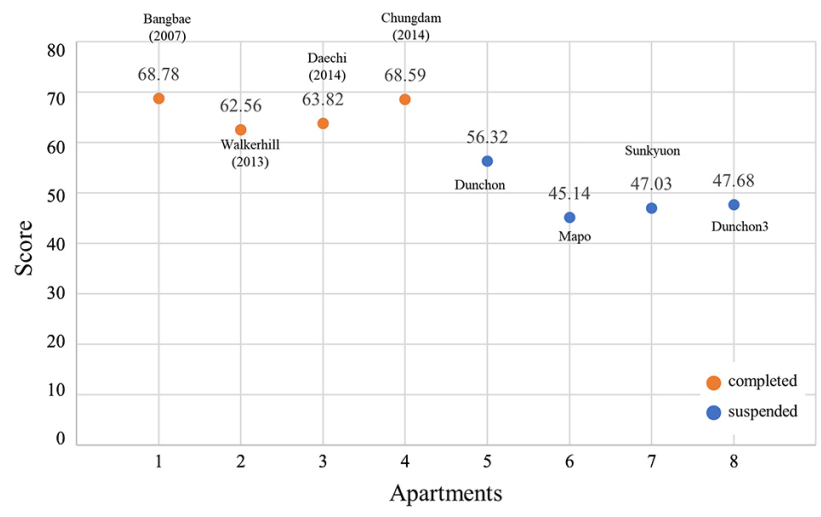

Figure 6. Result of technical feasibility study on completed and suspended apartments

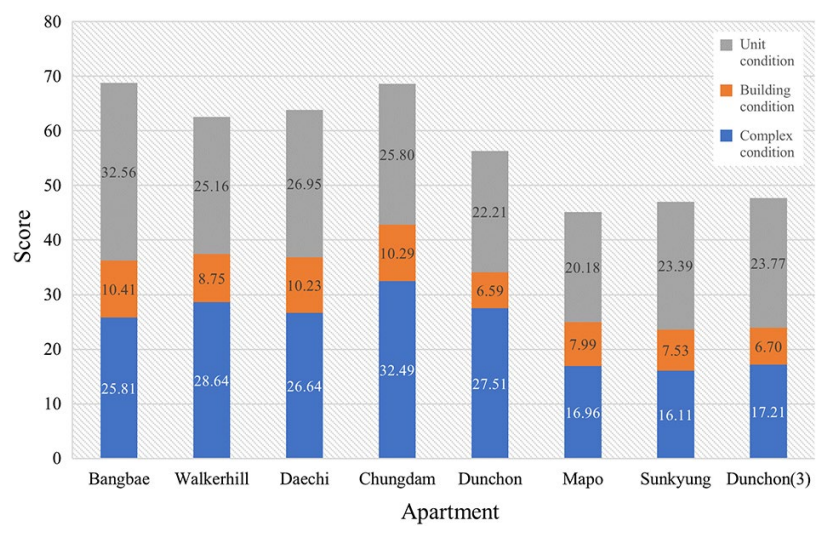

Figure 7. Detailed results of the technical feasibility study for completed and suspended apartments

If the suspended apartments had been evaluated in detail using this technical feasibility study model, it would have been possible to derive the complex, building, and unit scores of the apartments for renovation and the scores of detailed criteria. Moreover, it would be possible to identify and prepare for technical risks in advance of the process of apartment renovation planning and design.

\subsection{Application of model to apartments in progress}

The Jamwon and Songpa apartments were selected as renovation project apartments in progress (Figure 8). By comparing two apartments of similar size and project 

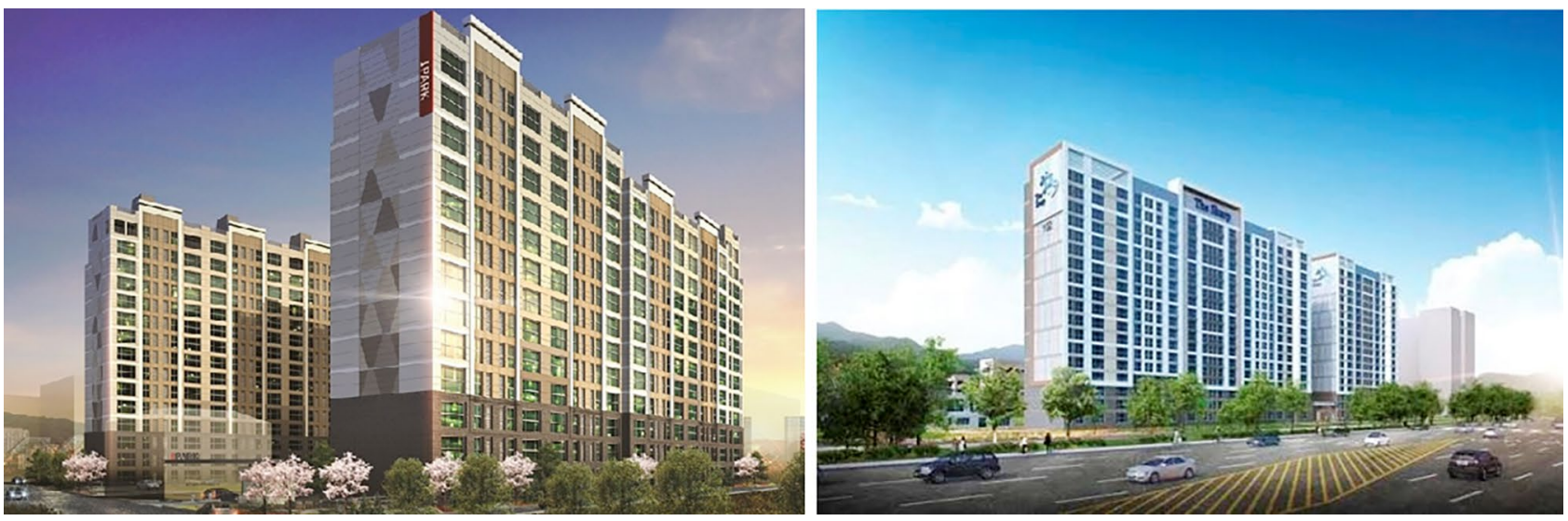

Figure 8. Renovation project apartments in progress

schedule, we examined the difference in renovation technical feasibility.

The Jamwon and Songpa complexes are each located in Seocho-gu and Songpa-gu, Seoul, and contain 208 and 298 households, respectively, across two buildings. The Jamwon complex consists of two buildings, one I-shaped and the other L-shaped, and the Songpa complex consists of two L-shaped buildings. The two apartments differ most in their foundation and building-parking structures.

For the two apartments, the technical feasibility was evaluated by applying it to the renovation technical feasibility study model (Table 6). The Jamwon apartment showed an evaluation score of 46.26, the Songpa apartment scoring 62.45. Considering the completed/suspended apartment evaluation results, the Songpa apartment had a high technical feasibility for renovation, but the Jamwon apartment had technical difficulties.

The Jamwon apartment had limitations in that it was difficult to extend to the rear owing to the limitations of ancient lights, making it difficult to reinforce the structure. In particular, it was found that the reinforcement of the pile foundation posed significant renovation difficulties. Currently, the Songpa apartment has passed a safety review and has been approved for renovation, but the Jamwon apartment has not yet passed its safety review, the project remaining undecided. In some cases, a complex project with a high technical feasibility evaluation score progresses faster.

Table 6. Results of technical feasibility study on renovation project apartments in progress

\begin{tabular}{|c|l|l|c|c|c|c|}
\hline \multirow{2}{*}{ ID } & \multirow{2}{*}{ Location } & \multirow{2}{*}{ Apartment } & \multicolumn{4}{|c|}{ Technical Feasibility Study Score } \\
\cline { 4 - 7 } & & & Complex & Building & Unit & Total \\
\hline 1 & Seoul & Jamwon & 16.54 & 7.16 & 22.56 & 46.26 \\
\hline 2 & Seoul & Songpa & 26.43 & 10.86 & 25.16 & 62.45 \\
\hline
\end{tabular}

\section{Conclusions}

The purpose of this study was to develop a technical feasibility study model that could evaluate the renovation of an aged apartment from a technical point of view. To this end, 27 aged apartment technical feasibility criteria were selected based on previous studies, and an AHP analysis was performed with ten renovation experts to derive the relative weight of the criteria. Based on the derived criteria weights, the SAW method was applied to derive an aged apartment renovation technical feasibility study model.

The proposed model was verified in two steps. First, verification was conducted on eight apartments where a renovation project was carried out. Through this, it was confirmed that there was a difference in the technical feasibility scores of the apartments that were completed versus those that were suspended. Moreover, the evaluation model was applied to apartments currently in the process of being renovated to determine the possibility of the renovation project being completed.

This study derived a model that could quantify and evaluate the technical aspects of the feasibility evaluation, which to date has only been conducted on the basis of economic feasibility, in the renovation of aged apartments. Using this model, it would be possible to evaluate the renovation feasibility from various angles and to identify the technical risks to be considered in the initial stage of a renovation project. In the future, the evaluation model could be developed based on more renovation cases.

We examined the technical feasibility of the renovation of residential buildings based on 27 criteria. To apply this model to residential apartment renovation projects under various conditions, further studies are necessary, including comprehensive criteria (e.g., height of the water table, adjacent facility interference, etc.) and national construction standards (e.g., construction Products Regulation). In addition, for the renovation of a residential building that considers sustainability, a feasibility evaluation considering social, economic, and environmental aspects together is necessary.

\section{Notations}

\section{Abbreviations}

AHP - Analytic hierarchy process;

SAW - Simple addictive weighting. 


\section{Funding}

This work was supported by the Residential Environment Research Program funded by the Ministry of Land, Infrastructure and Transport of the Korean government under Grant [number 21RERP-B099826-07].

\section{Author contributions}

Junho Choi and Jaepil Choi proposed the original idea and conducted the study. Junho Choi contributed to the conceptualization and organized the model, analyzed the data, and prepared the draft. Jaepil Choi contributed to project administration and finalized the paper. All authors contributed to authoring this paper.

\section{Disclosure statement}

The authors declare no conflict of interest.

\section{References}

Abastante, F., Corrente, S., Greco, S., Ishizaka, A., \& Lami, I. M. (2018). Choice architecture for architecture choices: Evaluating social housing initiatives putting together a parsimonious AHP methodology and the Choquet integral. Land Use Policy, 78, 748-762. https://doi.org/10.1016/j.landusepol.2018.07.037

Ahmed, W., \& Asif, M. (2020). BIM-based techno-economic assessment of energy retrofitting residential buildings in hot humid climate. Energy and Buildings, 227, 110406. https://doi.org/10.1016/j.enbuild.2020.110406

Baek, C.-H., \& Park, S.-H. (2012). Changes in renovation policies in the era of sustainability. Energy and Buildings, 47, 485-496. https://doi.org/10.1016/j.enbuild.2011.12.028

Bianchi, M., Ferrari, C., Melino, F., \& Peretto, A. (2012). Feasibility study of a Thermo-Photo-Voltaic system for CHP application in residential buildings. Applied Energy, 97, 704-713. https://doi.org/10.1016/j.apenergy.2012.01.049

Biekša, D., Šiupšinskas, G., Martinaitis, V., \& Jaraminienė, E. (2011). Energy efficiency challenges in multi-apartment building renovation in Lithuania. Journal of Civil Engineering and Management, 17(4), 467-475.

https://doi.org/10.3846/13923730.2011.622408

Boeri, A., Gabrielli, L., \& Longo, D. (2011). Evaluation and feasibility study of retrofitting interventions on social housing in Italy. Procedia Engineering, 21, 1161-1168.

https://doi.org/10.1016/j.proeng.2011.11.2125

Cha, W.-C., Lim, B.-W., Shin, C.-H., Shin, B.-H., Lee, J.-S., \& Chun, J.-Y. (2008). Availability evaluation system for remodeling of existing apartment houses. Korean Journal of Construction Engineering and Management, 9(5), 204-213.

Chen, Y.-C., Yu, T.-H., Tsui, P.-L., \& Lee, C.-S. (2014). A fuzzy AHP approach to construct international hotel spa atmosphere evaluation model. Quality \& Quantity, 48(2), 645-657. https://doi.org/10.1007/s11135-012-9792-2

Choi, J., \& Choi, J. (2021). A study on the technical feasibility evaluation index of aged apartment remodeling through Delphi method - focused on vertical and horizontal extension remodeling. Journal of the Architectural Institute of Korea, 37(2), 25-33.

Choi, J., Choi, J., \& Choi, S. (2017). A study on the development of an algorithm for optimizing area calculation in vertically extended apartments. Journal of the Architectural Institute of
Korea Planning \& Design, 33(2), 23-32.

https://doi.org/10.5659/JAIK_PD.2017.33.2.23

Choi, J., Choi, J., Kim, Y., \& Moon, S. (2018). Development of remodeling prototype plans in 1 st-phase new town aged apartment - based on ' 2 bay type' of 1 st-phase new town representatives. Journal of the Architectural Institute of Korea Planning \& Design, 34(6), 67-76.

Choi, J., Kang, H., \& Lee, Y. (2011). Design guidelines for the extension of aged apartment remodeling. Journal of Architectural Institute of Korea, 27(1), 19-28.

Ehyaei, M., Ahmadi, P., Atabi, F., Heibati, M., \& Khorshidvand, M. (2012). Feasibility study of applying internal combustion engines in residential buildings by exergy, economic and environmental analysis. Energy and Buildings, 55, 405413. https://doi.org/10.1016/j.enbuild.2012.09.002

Hopkins, D. C., Arikan, M., \& Sharpe, R. (2006). Benefit-cost study for 369 apartment buildings in Istanbul. In Proceedings of the NZSEE Conference, Napier, New Zealand.

Kafel, K., Leśniak, A., \& Zima, K. (2019). Multicriteria comparative analysis of pillars strengthening of the historic building. Open Engineering, 9(1), 18-25. https://doi.org/10.1515/eng-2019-0003

Kaklauskas, A., Tupenaite, L., Kanapeckiene, L., \& Naimaviciene, J. (2013). Knowledge-based model for standard housing renovation. Procedia Engineering, 57, 497-503. https://doi.org/10.1016/j.proeng.2013.04.064

Kim, J., \& Cha, H. (2018). Development of estimation system for housing remodeling cost through influence analysis by design elements. Korean Journal of Construction Engineering and Management, 19(6), 65-78.

Kim, Y.-W., Choi, Y.-J., \& Baek, S.-Y. (2020). Examining the natural ventilation performance of alternative designs for extension - Remodeling of aged apartments - experimented on corridor type units ranging 49 52 square meters found in Jeollabuk-do. Journal of the Architectural Institute of Korea, 36(11), 3-13.

Koh, W.-k., Yoon, J.-s., Yu, I.-h., Shin, D.-w., \& Jung, D.-w. (2019). Development of a feasibility evaluation model for apartment remodeling with the number of households increasing at the preliminary stage. Korean Journal of Construction Engineering and Management, 20(4), 22-33.

Korea National Housing Corporation. (2001). Design - guideline for the remodeling of wall-slab apartment. Korea.

Kragh, J., \& Rose, J. (2011). Energy renovation of single-family houses in Denmark utilising long-term financing based on equity. Applied Energy, 88(6), 2245-2253.

https://doi.org/10.1016/j.apenergy.2010.12.049

Lai, Y.-T., Wang, W.-C., \& Wang, H.-H. (2008). AHP- and simulation-based budget determination procedure for public building construction projects. Automation in Construction, 17(5), 623-632. https://doi.org/10.1016/j.autcon.2007.10.007

Ministry of Construction and Transportation. (2001). Building design standard checklist considering remodeling. Korea.

Ministry of Land and Maritime Affairs. (2011). Evaluation manual according to housing performance grade recognition and management standard revision. Korea.

Moon, G.-J. (2020). The negative perceptions of apartment culture as represented in Korean films during the 1970s-1990s. Sustainability, 12(7), 3013. https://doi.org/10.3390/su12073013

Mulliner, E., Malys, N., \& Maliene, V. (2016). Comparative analysis of MCDM methods for the assessment of sustainable housing affordability. Omega, 59, 146-156.

https://doi.org/10.1016/j.omega.2015.05.013 
Ouyang, J., Wang, C., Li, H., \& Hokao, K. (2011). A methodology for energy-efficient renovation of existing residential buildings in China and case study. Energy and Buildings, 43(9), 2203-2210. https://doi.org/10.1016/j.enbuild.2011.05.005

Paiho, S., Sepponen, M., Abdurafikov, R., Nystedt, Å., Kouhia, I., Meinander, M., \& Hoang, H. (2012). Feasibility on upgrading Moscow apartment buildings for energy efficiency. In 7th International Cold Climate HVAC Conference, Calgary, Alberta, Canada.

Seo, S.-Y., Lee, B., \& Won, J. (2021). Constructability analyses of vertical extension methods for existing underground spaces. Sustainability, 13(7), 3647.

https://doi.org/10.3390/su13073647

Tan, Y., Liu, G., Zhang, Y., Shuai, C., \& Shen, G. Q. (2018). Green retrofit of aged residential buildings in Hong Kong: A preliminary study. Building and Environment, 143, 89-98. https://doi.org/10.1016/j.buildenv.2018.06.058

Tupenaite, L., Zavadskas, E. K., Kaklauskas, A., Turskis, Z., \& Seniut, M. (2010). Multiple criteria assessment of alternatives for built and human environment renovation. Journal of Civil Engineering and Management, 16(2), 257-266. https://doi.org/10.3846/jcem.2010.30

Yeon, J., Lee, H.-S., Park, M., Kim, S., \& Ahn, J. (2014). Feasibility study on remodeling project by using real option model: Focusing on apartment house remodeling. Korean Journal of Construction Engineering and Management, 15(1), 39-50. https://doi.org/10.6106/KJCEM.2014.15.1.039

Yoon, J., \& Yu, I. (2019). Estimating normal duration of renovation for multistory apartment building considering extension-type renovation projects. Journal of Civil Engineering and Management, 25(2), 156-167.

https://doi.org/10.3846/jcem.2019.8024 